\title{
Conceptualizing Muslimat NU Women in Banyumas: A Civil Society Framework*
}

\author{
1Sofa Marwah, Oktafiani Catur Pratiwi, ${ }^{2}$ Soetji Lestari \\ ${ }^{1}$ Department of Political Science \\ Jenderal Soedirman University \\ ${ }^{2}$ Department of Sociology \\ Jenderal Soedirman University \\ Purwokerto, Indonesia \\ E-mail : sofamarwah75@gmail.com
}

\begin{abstract}
This paper attempts to conceptualize the existence of women organization of Muslimat NU (Nahdlatul Ulama) in Banyumas regency in the frame of civil society. It is significant to conduct a study since Muslimat NU in this regency is supported by two district organizing boards, adequate human resources, culturally and socially strong bond, consistently striving for religious and social improvement. This is a qualitative research by selecting chairperson and its boards of Muslimat NU Banyumas and Muslimat NU Sokaraja along with the lower level boards. The data were gathered through interview, FGD (Focus Group Discussion), observation and library research. The result shows thatMuslimat NU women of Banyumas and Sokaraja separates from political and economic power; they place themselves as lifeworld based on its basic principle of spreading virtues for religion, family and community. Even so, placing Muslimat NU women as a power of civil society which enables to act collectively is not a simple issue. This cannot be separated from the widening of social contract to sexual contract apparently seen in Muslimat NU struggle. To some extents, it still takes account of male dominance in decision making. Furthermore, the significant contribution of Muslimat NUBanyumas and Muslimat NU Sokaraja has not urged local government on particular issue. The consistency of their struggle for social and religious improvement concurrently seems to keep Muslimat NU at a distance from political knowledge and experience.
\end{abstract}

Keywords: civil society; lifeworld, Muslimat NU; women groups

\section{INTRODUCTION}

The dynamics of civil society in Indonesia will not be separated from the dynamics of Nahdlatul Ulama (NU) as the largest Islamic mass organization in this republic. NU was established as a religious organization relying on one of the four mahdzabs as a framework for understanding the Qur'an and Hadith. Established on January 31, 1926 as a nonpolitical mass organization, NU turned into a political organization in 1952 and became one of the participants of the first Indonesian Election in 1955. At that time, NU Party seized significant votes by $18.4 \%$ occupying the 3 rd position which deserved 45 seats in parliament. ${ }^{1}$ Since the New Order came to power in 1966 which implemented repressive policies, this party joined the United Development Party (PPP). In the implementation of the $27^{\text {th }}$ Congress in Situbondo 1983, the Party decided to quit the party and returned to a non-political mass organization or commonly referred back to Khittah 1926.

Through long lasted dynamics, NU still shows its formal consistency by proclaiming themselves as a non-political party. Past internal frictions including conflict among NU elites, New Order interference, jeopardizing Ulama for different political perspective "could be wellsettled". By doing so, NU confirms that it is not a political party, rather, the largest Islamic organization in Indonesia. Even, they did not use the opportunity the reform era gave which widely opens NU for political party. NU merely facilitated the establishment of the National Awakening Party (PKB), an openyet Muslimdominated political party.

The reading of the $\mathrm{NU}$ dynamics as a religious social organization changing to political party and finally returning to Khittah 1926 would not be comprehensive unless discussing the existence of Muslimat NU and Fatayat NU. Both women organizations holdexceptional mass strength comprised of the Ahlu Sunnah waljamaah and consistently follow the NU struggle as a religious social organization. Membership of Muslimat NU consists of Indonesian women aged 40 yearsoldand over or already married while the Fatayat NU consists of younger women, less than 40 years old. Several studies on NU women's organizations include Monika Arnezwho reviewed the women empowerment strategies conducted by Fatayat 
NU along with its resistance to paternal organization. Since the late 1990s, Fatayat NU has declared women empowerment as one of the main objectives of the organization based on gender interpretation in accordance with Islamic sources as the basis of legitimacy. 2Besides, Hamidah studied the dynamics of the Muslim women's movement in Indonesia, especially the Muslimat-Fatayat NU during the period 19382013. She found that the Indonesian Islamic women movements exist not only as the tahrirulmar'ahmovement of but also the influence of Muslim women's movement in the West. ${ }^{3}$ Similar study conducted by Linda Dwi Eriyanti identified the feminist perspective in NU non-mainstream women's political thought marked by radical feminist ideas. ${ }^{4}$ Meanwhile, Lailatul Syukriyah examined the birth and historical development of Muslimat NU during 1946-1955 and Muslimat NU support to NU Party in the 1955 General Election. ${ }^{5}$ Meanwhile, a specific study of gender discourse in NU women's movement was conducted by Dian Eka Rahmawati concerning the involvement of $\mathrm{NU}$ gender activists that shows feminism ideas, the strengthening of democratic issues in Islam, and the effects of civil society development introduced by NGOs or new social movements. ${ }^{6}$

Furthermore, this study would like to fill the gap among the aforementioned studies that did not portray Muslimat NU as a Muslim women group ofcivil society strength, because they do not have the political orientation. The selection of Muslimat NU as the locus of the study takes account that, like NU and Fatayat NU, Muslimat $\mathrm{NU}$ has quantitatively extraordinary women resources and is consistent in struggling for the women life quality in terms of Islamic $d a$ 'wah, education, health, social and so on. Therefore, this paper will conceptualize the women struggleinMuslimat NU as civil society forces by taking Muslimat NU in Banyumas Regency as the locus. Muslimat NU in Banyumas Regency is unique because it is supported by the existence of two branches within regency namely the branch of Muslimat NU Banyumas and Muslimat NU Sokaraja. Accordingly, to mention the two branches, the author uses the term Muslimat NU in Banyumas which includes Muslimat NU Banyumas and Muslimat NU Sokaraja. Then, this paper is divided into five parts; the first section

The Project Supported by Research of Social, Humaniora and Education, the Ministry of Researh Technology and Higher Education, 2017. contains an introduction of the importance of studying Muslimat NU in Banyumas within the framework of civil society; second part discussesresearch method; the third part tells the historical social dynamics of Muslimat NU in Banyumas; the fourth section explains the existence of Muslimat NU in Banyumas as a lifeworld space between political and economic power; the fifth section explicates the idea of the Muslimat NU in Banyumas as the power of civil society; and the sixth part is the closing remarks.

\section{RESEARCH METHOD}

This is a qualitative research which attempts to construct a detailed and comprehensive social phenomenon. This research aims to conceptualize Muslimat NU potentials in Banyumas in civil society framework. To do so, data collection were conducted by interview, FGD, observation and library research for complete data and information. ${ }^{7}$ Then, informants were purposively selected in accordance with the required criteria in this research, ${ }^{8}$ which involved the chairperson and organizing board of Muslimat NU Banyumas,chairperson and organizing board of Muslimat NU Sokaraja, along with the boards of their lower levels. Data analysis were concurrently conducted which means that both data analysis and treatment were carried out during data collection while analysis technique started from data clarification, theoretical abstraction upon the gathered data then formulated basic statements and finally drawing conclusion. ${ }^{9}$

\section{MUSLIMAT NU IN BANYUMAS : SOCIAL AND HISTORICAL DYNAMIC}

The history of Muslimat NU Sokaraja and Muslimat NU Banyumas cannot be separated from the early days of the National Muslimat NU establishment. NU women of Sokaraja led by Sulimah were involved in the $14^{\text {th }}$ NU Conference in Magelang in 1939. BesidesSokaraja, there were the women of NU coming from Muntilan, Kroya, Wonosobo, Surakarta, Magelang, and Purworejo. They attended the convention and held a preparatory meeting for the establishment ofMuslimat organization. Each delegate expressed their views on the importance of women contribution to family and society. Sulimah is one of the leaders who delivered a speech on the importance of the mother's role in child education which consequently education was also important for mother.

The further preparation forMuslimat establishment the establishment was achieved during the implementation of the 15th NU 
Conference in Surabaya in 1940. During the convention, the women of NUheld meetings on several general views such as; 1 ) Approval of the Muslimatpresence by the convention; 2) Muslimat Articles of Association; 3) Management Arrangement; 4) The curriculum for female madrasah education; and 5) Monthly publication plan. Muslimat at that time was led by Hindun from Surabaya.

By the NU's 16th Congress in Purwokerto in 1946, Muslimat NU was officially established through acclamation. At that time the head of the Muslimat was Chadijah Dahlan. At the 17th NU Congress in Madiun in 1948, there were commissioners of Muslimat committees in various regions, namely Madiun, Surabaya, Banyumas (Sokaraja), Kedu, Cirebon, Priangan (Tasikmalaya), Jember (Besuki), Malang and Tapanuli . In this context, Banyumas commissioner was chaired by Sulimah from Sokaraja. 10

Due to the involvement of Muslimat NU Sokaraja in pioneering the establishment of national Muslimatsince 1939 until present, Banyumas has 2 (two) branches of Muslimat NU in district level that is Muslimat NU Banyumas and Muslimat NU Sokaraja. There is a presumption that the embryo of the Muslimat NU formation actually came from Sokaraja, thus, they persisted to stand as Muslimat NUSokaraja. As a matter of fact, in one district, there is only one branch of Muslimat NU.

When the New Order came to power in the 1990s, there was a law requiring that there was only one branch of the organization in one district. As a result, Muslimat NU Banyumas and Muslimat NU Sokaraja merged. However on April 12, 2015, Muslimat NU Sokaraja separates from Muslimat NU Banyumas, after joining for 12 years. It was also triggered by the regressive condition of Muslimat NU Sokaraja as a change of leadership from Nur Kamilah to Laely Mansyur. The existence of two branches in one district is possible in the articles of association ofNational Muslimat NU during the Reform Era. As the pioneer organization prior to Muslimat NU Banyumas, Muslimat NU Sokaraja separated from Muslimat NU Banyumas.

Viewed from the two branches existence, the condition can show the prospective strength. Nevertheless, there are potential problems since Muslimat NU Sokaraja feels that three branches are reluctant to rejoin. Of the 27 branches in Banyumas, only six joined Muslimat NU Sokaraja involving Kembaran, Sokaraja, Kali Bagor, Banyumas, Somagede, and Tambak while the rest joined Muslimat NU Banyumas. In addition, there are several branches which are currently joining Muslimat NU Sokaraja want to join the Muslimat NU Banyumas.

\section{IDENTIFICATION OF MUSLIMAT NU STRENGTH IN BANYUMAS REGENCY: LIFEWORLD BETWEEN POLITIC AND ECONOMIC POWER}

This sub-chapter is intended to identify the strength of Muslimat NU in Banyumas as a space of social life, in which the individual's actions are far from seeking political power and economic profit. For a clearer illustration, this paper employs Habermas' social life scheme. Social life according to Habermas consists of two dimensions, namely system and lifeworld. System is an area of life integrated by a particular object, covering political and economic areas. Objects that drive action in the political area are power while in the economic area is money. Beyond the system is lifeworld, the area of life where the people actions are not driven by desire to accumulate power or money; rather, by the basic values that arise in social life such as justice, truth, and goodness. ${ }^{11}$

Referring to the lifeworld area above, what Muslimat NU women in Banyumas dedicate leads to a real form of lifeworld. In this regard, the basic value they undertake is to promote women lives for the benefit of religion, family, society and nation. They are Muslimat NU women organizations based on high awareness or passion to develop this organization and benefit others. These potential resources are supported by socio-cultural bond as the NU's member powerful. They were born and raised as the NU's memberwhich encourages them to join Muslimat NU from young to old age. Even to follow theMuslimatactivities, they often travel far, especially for members and administrators of remote areas, by motorcycling or even using pickup or rent village transportation. Possessing strong social-cultural ties, they do not feel to necessarily have membership cards. The most important thing to them is to be a member of Muslimat NU instead of membership card. The social-cultural ties as members of the organization are much stronger than labeling themselves in a piece of card.

Nevertheless, despite abundant human resources support, not all administrators have equal capability. This is recognized as a constraint the organization development. Yet, the primary thing is that they carry out the duties and functions with full sincerity and 
responsibility. Even they sometimes do not know exactly the task of each field butthey are excited to carrying out their duties for it is a mandate. They are women portraits who sincerely serve the organization, helpful by expecting nothing in returns/salary. In line with this, the study of Miftahul Huda revealed that Muslimat NU women in contributing to education, health, and other religious social fields rely on a strong spirit of motherhood.12 They are also a group of women who are very diligent in following the activities, diligent to record each meeting result, implementing each leader's instruction, record the training result and other activities. Particularly at the branch level of Muslimat NU Banyumas, they already have an annual work program and annual activity report.

In terms of networking, Muslimat NU women are already incorporated in the Joint Women's Organization (GOW), especially for Muslimat NU Banyumas. At least the network enables this organization contribution to women's progress without intending to push them into the power structure. In addition, other networks are more commonly formed under NU including the NU Student Association (IPNU), NU Women's Student Association (IPPNU), Anshor, Fatayat NU as well as the traditional network such aspesantren(Islamic boarding school), kyai(head of pesantren) and his wife.

In terms of funding, Muslimat $\mathrm{NU}$ is an independent organization without sponsorship in their activities. Fundraising is done based on the value of sincerity in various mechanisms. This is reflected in how Muslimat NU Banyumas and Muslimat NU Sokaraja raise funds from membership fees locally known as kalenganorpithian. The funding starts from the district level to the village level. Kalengan or pithiansystems are performed during routine weekly, monthly, or annual religious gatherings. The fee is voluntary ranging from $\mathrm{Rp} 2000$ but due to large participants in every gathering, it enables them to collect hundreds of thousands to millions rupiah. The collected funds is used to finance Muslimat activities at each level, or also deposited from lower to higherbranch. In fact, they can often donate programs outside the Muslimat activities, such as supporting a mosque building, NU Building, and so on.

Other fundraisings are performed including selling various Muslimat NU attributes such as calendars, Muslimat uniforms, hijab, scarf, groceries during exhibitions or bazaars. At the subdistrict level, the organization saving can reach 25 million at least. Even, Jatilawang branch can buy rice from the organization's cash, while Patikraja branch can build its own Muslimat building. For the branch level, the organization's cash is certainly larger obtaining from prescribed fees and voluntary contributions. The official fee requires every member to pay monthly fee of $\mathrm{Rp}$ 1,000. Besideskalengan method, Muslimat NU Banyumas cash also derives from PAUD and Diponegoro kindergarten management.

In contrast to Muslimat $\mathrm{NU}$ in rural areas, the sub district branch in urban areas experience different situations. This is because the number of jama'ah(participants) who attend religious gathering or other activities is relatively limited. Unlike in rural areas involving thousands of attendees, Muslimat NU branch activities in urban areas was only attended by the chairperson and secretary of the branch. Fortunately, urban people contribute more dues, usually Rp 10,000 for each. However, the total funds are relatively limited resulting in the limited branch inventory. There are only four branches of Muslimat NU Banyumas in urban areas, namelyWest Purwokerto,East Purwokerto, South Purwokerto, andNorth Purwokerto.

Muslimat NU funding is also supported by waqf. The waqfis more commonly received in the form of land or commonly called as conventional waqf. Of the 23 Kindergarten Diponegoro owned by Muslimat NU Banyumas, almost all the land is waqf.

The above description shows the high commitment of each board and members to raise Muslimat NU Banyumas and Muslimat NU Sokaraja in their own way by donating money, ideas, energy, food, goods, land, and so on. All is done based on value of sincerity for the advancement of women's lives which also contribute to the family, religion, society and nation. In other words, in the lifeworld area, according to Habermas, a public sphere is created wherein its citizens in this case Muslimat NU women groups-can express these values independently through the established social institutions, the civil society. It means that it is in the lifeworld space the Muslimat NU women group expresses its spirit to work and contribute to others, to family, religion, society and nation.

\section{DISCLOSING THE CAPACITY OF MUSLIMAT NU BANYUMAS IN THE FORMULATION OF CIVIL SOCIETY}

Referring to Muthiah Alagappa's explanation, civil society is a separate space for organization, a reflective form of communication and discourse, the control of individuals or 
groups acting collectively and disseminating civilian apparatus to influence the state and its policies without intending to take state power indicating by non-profit driven activitiesrather than profit-driven acts. ${ }^{13}$ Observing the explanation, there are two elements; First, internally civil society characterizes separate organizations but becomes a reflective communication and discourse which enables them to act collectively; Second, the ability to influence state power without taking over the power itself.

The first element of civil society would disclosethe capacity ofMuslimat NU in Banyumas as organization. As the largest women's mass organization in Banyumas, Muslimat $\mathrm{NU}$ is supported by abundant resources. In particular, members of MuslimatNU are jami'yah (formal membership) and jama'ah (non-formal or cultural-based membership as $\mathrm{NU}$ ), thus, the bond is not only by the organization label but socio-culturally deep-rooted bond. They have resources from the district level to the village level, even supported by two administrators namely Muslimat NU Banyumas and Muslimat NU Sokaraja. Not only by the quantitatively adequate number of resources,but also do they move from various levels to fight for fund independence to improve the quality of women lives. They also express their opinion due to strong social-cultural connections. They act to promote women lives and work voluntarily even without expecting returns.

Nonetheless, it should be noted that placing women groups as elements of civil society is notsimple issue. The existing patriarchal law might contribute to "difficulties" in placing women groups as civil society forces. Referring to Carole Pateman's notion on sexual contract, it states that classical social contract theory contains a pressure dimension namely patriarchy. Men have freedom and become heads of families who can take a leading role in social contracts. ${ }^{14}$ In this context, the involvement of women inMuslimat NU activities, either Muslimat NU Banyumas or Sokaraja would be none unless being supported by their husbands or relatives. Their activities in organization are only possible with husband's permission. Otherwise, they are unlikely to fully engage in such social-religious activities. This condition is affirmed by the two branch leaders of Muslimat NU Banyumas and Muslimat NU Sokaraja, Laely Manshur and Muslimah.

Viewing patriarchy from Pateman's perspective, the situation is a portrait of how the sexual contract either successfully or not touches Muslimat NU activities. They find it difficult to be integrated as a full civil society force. Perhaps this women organization is not ordinary society member;rather, they are a group of people who have space to work, apart from political power and economic profit. Yet, at some point, patriarchal law still prevails behind their actions in raising MuslimatNU and social contribution.

Patriarchy also dominates in Muslimat NU program, in terms that they have to wait for Kyai's (male) to for instance, build a construction. Kyai's blessing becomes the last reference to be obeyed, whether a program is feasible to be implemented or not. Even in the context of joining and separating the two Muslimat NU Banyumas and Muslimat NU Sokaraja, it was also executed after gaining blessing from Kyai. In this regard, Musdah Mulia once stated that Gus Dur was a leading figure campaigning gender equality among kyais and pesantrens. ${ }^{15}$ Consequently, patriarchal law in NU body faded.

However, in the context of this study, the kyai (male) figure is still important for Muslimat $\mathrm{NU}$ in Banyumas in decision making. In Pateman's view, the development of contemporary social contracts, such as marriage social contracts, employment, representation, and even social contracts in prostitution tend to support male freedom and women subordination. For this argument, Pateman claimed that in practice civil society cannot simply become universally applicable to women.

Subordination of patriarchy towards women becomes a barrier to the establishment of women groups as a civil society force. Needless to say then, the idea of putting Muslimat NU women as a civil society element necessarily takes account of the context, space and time. This means that in a certain space and time, they may be part of the civil society's strength, but in other situations it is necessary to see the consistency as the civil society.

Second element of civil society explores the ability of Muslimat NU in Banyumas to affect state power without taking over the power. In this case, the existence of Muslimat NU in Banyumas, both Muslimat NU Banyumas and Muslimat NU Sokaraja have no capacity to influence local government policy. In other words, they do not have an orientation to urge particular issue on the local government. As a NUunderbow women organization, the existence of Muslimat NU consistently follows NU's policy to uphold Khittah 1926 and Lombok 1997 as 
non-political mass organizations. ${ }^{16}$ Areas of organization include; a) organization and membership; b) education and regeneration; c) social, population and environment; d) health; e) da'wah; f) economic, cooperative and agribusiness; g) labor; h) law and advocacy. Successes in various fields are mainly shown by Muslimat NU Banyumas underLaely Manshur's leadership. Till present, nevertheless, this organization has not been involved in crucial issues, such as local regulations that are urgently to be drafted by the local administration. Within the framework of civil society formulation, their work areas at the end are not in contact with efforts to urge important issues on power. In particular, they are not yet present to influence local government policy.

Muslimat NU has consistently shown itself as a non-political women organization. It seems common for political parties to approach this organization especially in the political moments such as legislative elections, gubernatorial elections, and regent elections. In this point, the administrators of Muslimat NU in Banyumas are aware of their low capacity to influence policy through the executive or legislative body. Thus, the idea of this paper is to place the potentials of Muslimat NU Banyumas and Muslimat NU Sokaraja if they are able to influence local government policy, in this context, cannot be fulfilled.

Even so, it is still possible to influence local government policy directly throughMuslimat $\mathrm{NU}$ cadres in legislative body either DPR or DPRD. The cadres of both organizations are allowed to enter politics even though they do not carry Muslimat NU names formally. Still, there is hope that those cadres can bring prosperity to the organizationeven though they are not allowed to bring formal Muslimat $\mathrm{NU}$ organizations.

Another proofof how this NU women organization is still far from regional power map is when Laely Manshur ran for Vice Banyumas paired with Singgih Wiranto in Banyumas Local Election in 2008. She was defeated in the territory in which shelled the branch of Muslimat NU Banyumas at the third term of office. Even she and her partner only occupied the third position of four couples who participated at that time. This is ironic regarding her capacity as chairperson of Muslimat NU Banyumas for three periods. It is true that the politics is very competitive and intense, but when it occurs, it is obvious the distance of Muslimat NU Banyumas with power. It seems they are lack of experience to involve inpolitical sphere.Historical records indicating that Muslimat $\mathrm{NU}$ had assisted the success of NU Party in the 1955 General Election and appealed to the $\mathrm{NU}$ central board for prioritizing the Muslimat members to be nominated as constituent candidates, 17left historical records only for Muslimat NU. Muslimat NU political experience has long disappeared. To conceptualize the existence of Muslimat NU Banyumas particularly Sokaraja to influence power atregional level as one element of civil society remains far from reality.

\section{CLOSING REMARKS}

As an organization, the MuslimatNU women group owns abundant resources, strong social-cultural bonding and consistent to support the organization as well as contribute to society on the basis of sincerity and responsibility. In this regard, the struggle for women's life progress, contribution to religion, society, and nation is a form of their consistency which always keeps at a distance from political power and economic profit. Their activities show real lifeworld area, away from approaching political power and profit-oriented activities. However, to conceptualize whether these reflect the power of civil society describing a separate organization and able to act collectively, at some point, is still in conflict with the patriarchal law including the importance of the husband's permission to join this organization or the importance of kyai (male) in certain decision making. In fact, initiating civil society means placing a group which is able to affect thestate power. In practice, the consistency of struggle in social-religious field has never reached the level to urge crucial and strategic issues to the local government. Instead, the consistency of Muslimat NU in the struggle for the social-religious field keeps them at distance from learning politics or gain political experience. As a result, they tend to be only used by certain actors before the political moments. It proves that political education is actually important to them although they do not involve practical politics organizationally. 


\section{ACKNOWLEDGMENT}

Special gratitude is expressed to Research of Social, Humanities and Education 2017, funded by the Ministry of Research Technology and Higher Education.

\section{REFERENCES}

Alagappa,M., 2004. Civil Society and Political Change in Asia, Stanford California: California University Press.

Arnez, M., 2010. "Empowering women through Islam : Fatayat NU between tradition and change" , Journal of Islamic Studies, Vol. 21 No.1,pp. 59-88.

Eriyanti, L.D., 2016. "Pemikiran politik perempuan Nahdlatul Ulama (NU) dalam perspektif feminisme: penelusuran pemikiran mainstream dan non-mainstream", JSP Jurnal Sosial dan Politik UGM, Vol. 20 No.1 July, pp. 69-83.

Feith, H.,1999. Pemilihan Umum 1955 di Indonesia, Jakarta : Gramedia.

Hamidah, 2016. "Indonesia Islamic movement of women: a study of Fatayat Muslimat NU (1938-2013)", Jurnal Miqot, Vol. XL No. 1 January-June, pp. 162-174.

Harrison, L., 2007. Metodologi Penelitian Politik, Jakarta: Kencana Prenada Media.

M. Huda, M., 2015. Motherhood spirit untuk kedermawanan sosial di Muslimat $N U$ Ponorogo, Jurnal Kodifikasi, Vol. No.1 2015, p. 37-60.

Mulia,M., 2015.“Gus Dur: pioner gerakan feminisme", in A. Nadjie,Gus Dur diMata Perempuan,Yogyakarta: PP Fatayat and Gading.

Muslimat NU, PP. 1979. Sejarah Muslimat Nahdlatul Ulama, Jakarta : PP Muslimat NU.

Punch, K., 2006. Developing Effective Research Proposal, London: Sage Publication.

Rahmawati, D.E, 2015. "Gender discourse and women movement in NU", Journal of Government and Politics UMY,Vol.6 No. 2 August, pp. 229-247.

Silbergh, D.M.,2001. Doing Dissertations in Politics: A Student Guide, London: Routledge.

Sullivan, B., 1998. "Carole Pateman: participatory democracy and feminism", in Carter, A. and Stokes, G., Liberal Democracy and Its Critics, Cambridge: Polity Press.
Syukriyah, L.,2016. "Muslimat NU di Indonesia (1946-1955)", Avatara Jurnal Pendidikan SejarahUnesa, Vol. 4, No. 3, October, pp. 609620.

White, S.K., 2002. "Skeptics at the celebration: civil society and the early Frankfurt School", in Rosenblum, N.Land Post, R.C., Civil Society and Government, Princeton: Princenton University Press.

${ }^{(1)}$ H. Feith, Pemilihan Umum 1955 di Indonesia, Jakarta : Gramedia, 1999.

${ }^{(2)}$ M. Arnez, "Empowering women through Islam : Fatayat NU between tradition and change", Journal of Islamic Studies,Vol. 21 No.1,2010, pp. 59-88.

${ }^{(3)}$ Hamidah, "Indonesia Islamic movement of women: a study of Fatayat Muslimat NU (1938-2013)", Jurnal Miqot, Vol. XL No. 1, January-June 2016,pp.162-174.

${ }^{(4)}$ L.D. Eriyanti, "Pemikiran politik perempuan Nahdlatul Ulama (NU) dalam perspektif feminisme: penelusuran pemikiran mainstream dan non-mainstream", JSP Jurnal Sosial dan Politik UGM, Vol. 20 No.1, July 2016, pp. 69-83.

${ }^{(5)}$ L. Syukriyah, "Muslimat NU di Indonesia (1946-1955)", Avatara Jurnal Pendidikan SejarahUnesa, Vol. 4 No. 3, October 2016,pp. 609-620.

(6) D.E. Rahmawati, "Gender discourse and women movement in NU", Journal of Government and Politics UMY, Vol.6 No. 2, August 2015, pp. 229-247.

${ }^{(7)}$ K. Punch, Developing Effective Research Proposal, London: Sage Publication, 2006, p.52.

${ }^{(8)}$ L. Harrison, Metodologi Penelitian Politik, Jakarta : Kencana Prenada Media, 2007, p.26.

${ }^{(9)}$ D.M. Silbergh, Doing Dissertations in Politics: A Student Guide, London : Routledge, 2001, p.173.

${ }^{(10)}$ PP Muslimat NU, Sejarah Muslimat Nahdlatul Ulama, Jakarta : PP Muslimat NU, 1979.

${ }^{(11)}$ S.K.White, "Skeptics at the celebration : civil society and the early Frankfurt School",in N.L. Rosenblum and R.C. Post, Civil Society and Government, Princeton : Princenton University Press, 2002, p. 146.

${ }^{(12)}$ M. Huda, Motherhood spirit untuk kedermawanan sosial di Muslimat NU Ponorogo, Jurnal Kodifikasi, Vol. No.1 2015, p. 37.

${ }^{(13)}$ M. Alagappa, Civil Society and Political Change in Asia, Stanford California: California University Press, 2004, p.9.

${ }^{(14)}$ B.Sullivan, "Carole Pateman : participatory democracy and feminism", in A. Carter and G. Stokes, Liberal Democracy and Its Critics, Cambridge: Polity Press, 1998, p.182.

${ }^{(15)}$ M.Mulia, "Gus Dur: pioner gerakan feminisme", in A. Nadjie, Gus Dur diMata Perempuan, Yogyakarta: PP Fatayat and Gading, 2015, pp. 69-70.

${ }^{(16)}$ Hamidah, op.cit., p.162.

(17) L. Syukriyah, op.cit., p. 619. 